\title{
THE ADDIS SEDIMENT COUNT AND BLOOD UREA CLEARANCE TEST IN NORMAI, PREGNANT WOMEN
}

\author{
By C. A. ELDEN and J. W. COONEY \\ (From the Department of Obstctrics and Gynecology, The University of Rochester School of \\ Medicine and Dentistry, Rochester, New York)
}

(Received for publication July 15, 1935)

Many tests have been done to evaluate renal function in the toxemias of pregnancy and investigators $(1,2,3,4,5)$ are agreed that the most accurate is the blood urea clearance. Addis (6, 7 ) has studied the urinary sediment in both normal and nephritic patients and is able by this means to classify the nephritides more accurately. These two tests are the most sensitive and accurate of any used to determine the character and extent of damage of the kidneys. However, there is a scarcity of Addis count values in normal pregnant women. Both tests have been used in this clinic to find the limits of variation in normal women in the last trimester of pregnancy, as a means of obtaining a better basis for comparison of values obtained in cases of toxemia, which have their onset during this period.

\section{METHOD}

On the first day the patient was admitted to the hospital after the usual breakfast including tea, coffee or milk. The patient was instructed not to drink more fluids or eat more fruit than usual for breakfast. The patient remained in bed until the completion of all tests and no fluids, “Anything That Can Be Poured," were given for twenty-four hours. The regular house diet exclusive of tea, coffee, milk or ice cream was given, but no more fruit than usual even if the patient complained of thirst. The bladder was emptied at 7.30 p.m. and the urine discarded. The patient was encouraged not to void after this time.

On the second day the following routine was carried out: breakfast was delayed until the completion of all tests. The patient was catheterized at 7.30 a.m. and the catheter retained in the bladder until the completion of all tests. The specimen of urine obtained at 7.30 was put in a bottle specially prepared for the Addis count. During the next two hours one liter of water was given to insure obtaining a sufficient volume of urine for measuring the urea clearance. At 9.30 a.m. the bladder was completely emptied, the urine discarded, and the patient was given $500 \mathrm{cc}$. more water. At 10.30 a.m. and again at 11.30 a.m. the bladder was completely emptied, both specimens of urine saved and the catheter removed. After the 10.30 catheterization a venipuncture was done and the patient was given $500 \mathrm{cc}$. more water. It is extremely important that the bladder be completely emptied on time and that the patient drink all of the water designated.

\section{LABORATORY PROCEDURE}

The urinary sediment count was done according to the method of Addis $(6,7)$. The urea of the blood and urine was determined by Van Slyke's method (8), and the blood urea clearance was calculated (9). The total proteins of the urine were determined in the supernatant urine in the Addis tube, according to the method of Shevky and Stafford (10).

\section{RESULTS}

In the accompanying table are the observations made of nineteen normal women in the last trimester of pregnancy, three of whom were multiparas and sixteen primiparas. The tests were done from 1 to 83 days antepartum. The blood pressures of these women were all within normal limits. The average values of the urea clearances for the first and second hours varied from 60 to 118 per cent of the average normal as established by Möller, McIntosh and Van Slyke (9), six being below 80 per cent. The total protein content of the urine was within normal limits. The cast count varied from 0 to 10,000 , except one case which showed a count of 14,000 . This patient had had acute pyelitis one year previously, a fact which may account for the high value. The red blood cell count ranged from 47,000 to $1,900,000$ 
TABLE I

The Addis urinary sediment count and blood urea clearance of normal pregnant women

\begin{tabular}{|c|c|c|c|c|c|c|c|c|c|c|}
\hline \multirow{2}{*}{$\begin{array}{l}\text { Case } \\
\text { num- } \\
\text { ber }\end{array}$} & \multirow{2}{*}{ Age } & \multirow{2}{*}{ Para } & \multirow{2}{*}{$\begin{array}{c}\text { Days ante- } \\
\text { partum }\end{array}$} & \multirow{2}{*}{$\begin{array}{c}\text { Blood } \\
\text { pressure }\end{array}$} & \multicolumn{2}{|c|}{ Urea clearance } & \multirow{2}{*}{$\begin{array}{c}\text { Protein- } \\
\text { uria }\end{array}$} & \multicolumn{3}{|c|}{ Addis count } \\
\hline & & & & & 1st hour & 2nd hour & & Total casts & R.B.C. & W.B.c. \\
\hline $\begin{array}{l}1 \\
2 \\
3 \\
4 \\
5\end{array}$ & $\begin{array}{c}\text { years } \\
18 \\
18 \\
35 \\
20 \\
21\end{array}$ & $\begin{array}{l}0 \\
0 \\
\mathrm{~V} \\
0 \\
0\end{array}$ & $\begin{array}{l}33 \\
31 \\
55 \\
32 \\
18\end{array}$ & $\begin{array}{l}m m . H g \\
120 / 70 \\
105 / 60 \\
120 / 60 \\
122 / 80 \\
130 / 70\end{array}$ & $\begin{array}{c}\text { per cent normal } \\
64.3 \\
68.2 \\
87.7 \\
70.0 \\
69.0\end{array}$ & $\begin{array}{c}\text { per cent normal } \\
79.6 \\
68.0 \\
105.0 \\
90.0 \\
102.0\end{array}$ & $\begin{array}{l}\text { grams } \\
.36 \\
.25 \\
.36 \\
.18 \\
.36\end{array}$ & $\begin{array}{c}7,500 \\
0 \\
14,000^{* *} \\
0 \\
7,400\end{array}$ & $\begin{array}{c}\text { thousands } \\
1,192 \\
285 \\
500 \\
367 \\
22,230\end{array}$ & $\begin{array}{c}\text { millions } \\
2.30 \\
0.60 \\
0.50 \\
3.18^{*} \\
6.00^{*}\end{array}$ \\
\hline 6 & 20 & 0 & 60 & $120 / 80$ & 122.8 & 96.8 & .18 & 9,900 & $\underset{8,300}{\text { Trauma }}$ & $2.30^{*}$ \\
\hline $\begin{array}{r}7 \\
8 \\
9 \\
10 \\
11 \\
12 \\
13 \\
14 \\
15\end{array}$ & $\begin{array}{l}17 \\
22 \\
32 \\
20 \\
24 \\
18 \\
23 \\
26 \\
18\end{array}$ & $\begin{array}{l}0 \\
0 \\
0 \\
0 \\
0 \\
0 \\
0 \\
0 \\
0\end{array}$ & $\begin{array}{l}25 \\
30 \dagger \\
42 \\
24 \\
30 \\
7 \\
42 \\
3 \\
16\end{array}$ & $\begin{array}{r}115 / 70 \\
130 / 90 \\
120 / 62 \\
120 / 60 \\
118 / 74 \\
90 / 60 \\
100 / 50 \\
116 / 60 \\
118 / 80\end{array}$ & $\begin{array}{r}85.5 \\
120.0 \\
51.2 \\
85.9 \\
68.0 \\
85.9 \\
62.5 \\
90.4 \\
88.4\end{array}$ & $\begin{array}{r}78.3 \\
105.0 \\
86.8 \\
75.0 \\
68.0 \\
74.6 \\
57.9 \\
80.0 \\
49.2\end{array}$ & $\begin{array}{l}.20 \\
.36 \\
\text { Trace } \\
\text { Trace } \\
.36 \\
.36 \\
.40 \\
.36 \\
.72\end{array}$ & $\begin{array}{r}0 \\
0 \\
0 \\
0 \\
10,000 \\
9,702 \\
0 \\
0 \\
0\end{array}$ & $\begin{array}{r}\text { Trauma } \\
1,943 \\
510 \\
1,000 \\
670 \\
570 \\
525 \\
440 \\
254 \\
4,810\end{array}$ & $\begin{array}{c}0.11 \\
2.00^{*} \\
3.15 \\
0.50 \\
0.62 \\
0.53 \\
0.55 \\
0.27 \\
12.90^{*}\end{array}$ \\
\hline $\begin{array}{l}16 \\
17 \\
18 \\
19\end{array}$ & $\begin{array}{l}25 \\
24 \\
22\end{array}$ & $\begin{array}{l}\text { II } \\
\text { III } \\
0\end{array}$ & $\begin{array}{r}1 \\
3 \\
1 \\
83\end{array}$ & $\begin{array}{l}110 / 50 \\
130 / 60 \\
100 / 60\end{array}$ & \begin{tabular}{|c|}
119.0 \\
132.0 \\
Not done- labor \\
78.0
\end{tabular} & $\begin{array}{r}103.0 \\
105.0 \\
\text { began } 84.0\end{array}$ & $\begin{array}{r}.30 \\
0 \\
.36 \\
.03\end{array}$ & $\begin{array}{r}1,000 \\
8,800 \\
0 \\
3,200\end{array}$ & $\begin{array}{r}\text { Trauma } \\
102 \\
310 \\
342 \\
47\end{array}$ & $\begin{array}{l}0.03 \\
0.62 \\
2.00 \\
0.10\end{array}$ \\
\hline
\end{tabular}

* Bacteriuria.

† 21 days following test, developed toxemia.

** Acute pyelitis 1 year ago.

except in those cases in which there was known to be definite trauma in catheterization. The white blood cell count ranged from 25,000 to $6,000,000$. In several instances there was a definite bacteriuria.

\section{DISCUSSION}

The values of the urea clearance established by Möller, McIntosh and Van Slyke (9) for nonpregnant normal subjects ranged from 80 to 120 per cent of the average normal clearance. We have found that the values ranged from 60 to 118 per cent of the average normal clearance in normal women in the last trimester of pregnancy, with one-third between 60 and 80 per cent. Therefore 60 per cent is probably the low limit of normal.

Addis found the urinary sediment of normal non-pregnant individuals to contain: casts 0 to 5,000; red blood cells 0 to 425,000 ; and white blood cells 32,000 to $1,000,000$. Our observations showed casts varying from 0 to 10,000 , with half of the cases having a count greater than 5,000, which is above the upper normal limit observed by Addis. The red blood cell count varied from 47,000 to $1,900,000$ except in three cases where there was definite trauma by the catheter. Among the remaining 16 cases, 5 showed an erythrocyte count greater than 500,000. The cell count of leukocytes and epithelium ranged from 25,000 to $6,000,000$ with 8 instances in which it was greater than $1,000,000$.

The wider limits of variation may be explained by the changes in the physiology and anatomy of women in the last trimester of pregnancy. Recently Coutts et al. (11) have demonstrated by aortograms of 12 women in the last trimester of pregnancy that the aorta is displaced to the left, that the renal arteries course upward and that the circulation in the common iliac arteries is altered. These facts suggest that pressure of the gravid uterus may alter the renal circulation. We have noted that patients after dehydration and catheterization usually secrete very little urine for the next 2 hours. This is in accordance with the findings of Dieckmann (5) who has called attention to the small volume of urine obtained antepartum with the larger volume obtained postpartum. The 
ureters may become dilated by the pressure of the gravid uterus, thus giving rise to stasis, and possibly to bacteriuria and to an elevated leukocyte count in the urinary sediment. In view of these changes, it seems reasonable to suppose that renal function may be secondarily altered, thus accounting for the lower values of the urea clearance and the larger number of formed elements in the urinary sediment of normal women in the last trimester of pregnancy, when compared with the values previously obtained by others in nonpregnant normal individuals.

\section{CONCLUSIONS}

In nineteen normal women during the last trimester of pregnancy, counts were made of the number of formed elements in the urinary sediment, and measurements made of the urea clearance.

1. In the urinary sediment, using the technique of Addis, casts varied from 0 to 10,000 ; the red blood cells from 47,000 to $1,900,000$; and the cell count of leukocytes and epithelium from 25,000 to $6,000,000$. These values are higher than the corresponding values hitherto observed in normal non-pregnant individuals.

2. The values of the urea clearance varied from 60 to 118 per cent of the average normal standard established by Van Slyke and coworkers. From this it is apparent that the lower limit of normal urea clearance is somewhat less than in 'nonpregnant individuals.

\section{BIBLIOGRAPHY}

1. Stander, H. J., Ashton, P., and Cadden, J. F., The value of the various kidney function tests in the differentiation of the toxemias of pregnancy. Am. J. Obst. and Gynec., 1932, 23, 461.

2. Harowitz, D., and Ohler, W. R., The urea clearance test in the toxemias of pregnancy. J. Clin. Invest., 1932, 11, 1119.

3. Cantarow, A., and Ricchiuti, G., Urea clearance test in pregnancy. Arch. Int. Med., 1933, 52, 637.

4. Cadden, J. F., and McLand, C. M., A study of various kidney function tests in relation to the toxemias of pregnancy. Surg. Gynec. and Obst., 1934, 59, 177.

5. Dieckmann, W. J., Renal function in the toxemias of pregnancy. Am. J. Obst. and Gynec., 1935, 29, 472.

6. Addis, T., The number of formed elements in the urinary sediment of normal individuals. J. Clin. Invest., 1926, 2, 409.

7. Addis, T., A clinical classification of Bright's disease. J. A. M. A., 1925, 85, 163.

8. Van Slyke, D. D., Determination of urea by gasometric measurement of the carbon dioxide formed by the action of urease. J. Biol. Chem., 1927, 73, 695.

9. Möller, E., McIntosh, J. F., and Van Slyke, D. D., Studies of urea excretion. II. Relationship between urine volume and the rate of urea excretion by normal adults. J. Clin. Invest., 1928, 6, 427.

10. Shevky, M. C., and Stafford, D. D., Clinical method for estimation of protein in urine and other body fluids. Arch. Int. Med., 1923, 32, 222.

11. Coutts, W. E., Opazo, L., Bianchi, T. B., and Donoso, O. S., Abdominal circulation during late pregnancy as shown in aortograms. Am. J. Obst. and Gynec., $1935,29,566$. 